\title{
Effects of Exchange Rate Variation on Price Level and Output Growth in Bangladesh
}

\author{
Abdullahil Mamun \\ Assistant Professor, Department of Business Administration, \\ International Islamic University Chittagong \\ Corresponding Author:E-mail: ahm_economics@yahoo.com, Cell No.: +8801712138373
}

Abdul Hamid Chowdhury

Associate Professor,Department of Business Administration, International Islamic University Chittagong

Shahanara Basher

Adjunct Lecturer,Department of Business Administration, International Islamic University Chittagong

\section{Doi:10.5901/mjss.2013.v4n6p205}

\begin{abstract}
The paper empirically examines the impact of depreciation on domestic output growth and price level of Bangladesh. Exchange rate along with some other traditional factors like investment spending, bank credit, narrow and broad money and labor force have been taken into account to evaluate the influence of exchange rate fluctuation on economic growth and price level of Bangladesh. The macroeconomic time series variables are made stationary to employ regression techniques. The study finds that depreciation has an expansionary effect on output level and price level and the overall result is consistent with the view that depreciation leads to inflation fostering the output growth.Depreciation, which is essential to regain export competitiveness, should be handled pragmatically to uproot its adverse implication on long term economic growth of Bangladesh that might occur due to import contraction.
\end{abstract}

Keywords: Depreciation, Economic Growth, Inflation.

\section{Prelude}

Influencing a country's export and import, exchange rate variations bring changes to trade balance and thereby may cause change to the price and output level of that economy which ultimately changes the income distribution of the economy (Kandil 2004, Kollmann 2005). Bangladesh has a significant external sector. The two components of our external resource balance, export and import, have been expanded remarkably. Despite the domestic and international inflationary pressure and ongoing spillover effects of the unstable external economic conditions, both exports and imports maintained growth rates above five percent.

Exchange rate fluctuations have significant implications for economic performance in Bangladesh. This is because fluctuation in exchange rate brings about changes in trade balance by influencing the country's export and import. Exchange rates may cause the price level to change and, as a consequence, it may change the income distribution of the economy (Agenor 1991, Montiel 1997).

The management of the exchange rate is considered to be a major policy objective in Bangladesh to achieve a set of diverse objectives of economic growth, containment of inflation and maintenance of external competiveness. Policy discussions regularly emphasize on it as the academic literature provides compelling evidence to suggest that a wrongly managed exchange rate regime can be a major impediment for improved economic performance (Khondker, $\mathrm{B}$. $\mathrm{H}$. et al, 2012). Depreciation of currency involves several types of effects on the economy. Depreciation affects the output and inflation objectives of the central bank through three different channels. First, depreciation directly affects the rate of inflation. The impact of depreciation on inflation will depend on the level of the pass-through. Second, depreciation 
affects output through a balance sheet effect: the depreciation increases the cost of repayment of foreign currency denominated debt, reducing profits in this period, and thus the capital stock and output in the second period. Third, a larger depreciation entails a smaller increase in interest rates. Thus, a larger depreciation increases output in the second period, since the reduction in interest rate eases the credit constraint (the credit channel effect). The overall effect on income will depend on which of the two channels dominate. If the credit channel dominates over the balance sheet channel, depreciation is expansionary. Otherwise, it is contractionary (Hossain and Ahmed, 2009). In judging the desirability of exchange rate fluctuations, it becomes, therefore, necessary to evaluate their effects on output growth and price inflation. Demand and supply channels determine these effects (Kandil2004).

In this backdrop, the currency of Bangladesh has been devalued and depreciated since independence against some of the foreign currencies to whom it was pegged with, especially against USD. In recent years, the impact of growing balance of payment pressure on exchange rate is evident (Table-1). In this context, the study is an attempt to evaluate the impact of exchange rate change on output growth and price level of Bangladesh economy.

\subsection{External Sector of Bangladesh Economy}

The external sector of Bangladesh is significant. Its overall performance somewhat improved by a higher current account surplus in 2012 compared to that of 2011. Total exports increased by 5.9 percent in FY12 to USD 24287.7 million from USD 22924.4 million in FY11 and import payments in FY12 increased from USD 30336 million in FY11 to USD 31987 million registering a growth of 5.4 percent. Workers' remittances increased by USD 1193.0 million to USD 12843 million in FY12 from USD 1650 million in FY11.

Table 1: Balance of Payments (Million US Dollar)

\begin{tabular}{|l|c|c|c|c|c|c|}
\hline Items & FY07 & FY08 & FY09 & FY10 & FY11 & FY12 \\
\hline Trade balance & -3458 & -5330 & -4710 & -5155 & -7744 & -7995 \\
\hline Current account balance & 936 & 702 & 2416 & 3724 & 885 & 1630 \\
\hline Financial account & 762 & -457 & -825 & -651 & -1920 & -955 \\
\hline Foreign direct investment (net) & 793 & 748 & 961 & 913 & 775 & 995 \\
\hline Other Investment & -137 & -1252 & -1627 & -1447 & -2667 & -2148 \\
\hline Overall balance & 1493 & 331 & 2058 & 2865 & -656 & 494 \\
\hline
\end{tabular}

Source: Statistics Department, Bangladesh Bank.

The current account surplus increases from USD 885.0 million in FY11 to USD 1630.0 million in FY12. Current account balance as a percentage of GDP stood at 1.4 in FY12 against 0.8 in FY11. One of the potential sources of our foreign exchange reserves is FDI. Despite global financial turmoil, domestic power and energy shortages, as per primary estimation net FDI inflows in Bangladesh increased by 28.4 percent to USD 995.0 million in FY12 from USD 775.0 million in FY11. The surplus in current account balance with the huge increase in both FDI (net) and portfolio investment in the financial account contributed to convert the Balance of Payment (BOP) deficit of USD 656.0 million in FY11 into a surplus of USD 494.0 million in FY12. Though there were strong inflows of foreign exchange through higher export receipts and remittances, but Bangladesh economy failed to speed up with higher import payments in fiscal year 2012, leading to a higher trade deficit in recent months. The trade deficit together with weak net capital account inflows forced the exchange rate to depreciate.

\subsection{Exchange Rate Movement and Intervention in the Foreign Exchange Market}

Bangladesh switched to floating exchange rate system on May 31, 2003. Earlier, Bangladesh had been maintaining various pegged exchange rate regimes, such as pegged to the British pound sterling (1972-1979), pegged to a basket of major trading partners' currencies with pound sterling as the intervening currency (1980-1982), pegged to a basket of major trading partners' currencies with US dollar as the intervening currency (1983-1999), and an adjustable pegged system (2000-2003).

Since the adoption of floating exchange rate system by abandoning the adjustable pegged system, exchange rate is being determined on the basis of demand and supply of the respective currencies. Banks are now free to set their own rates for interbank and customer transactions. However, Empirical evidence and theory suggests that floating exchange 
rates are characterized by little intervention in the exchange rate markets (Hossain and Ahmed, 2009). Bangladesh Bank remains vigilant over the developments in the foreign exchange market and it revises its monetary policy framework time to time in order to maintain orderly market conditions. Bangladesh Bank may purchase and sell US dollar as and when it thinks necessary to maintain stability in the foreign exchange market.

Just after the inception to floating regime, the exchange rate remained fairly stable experiencing a depreciation of less than 1 percent in the first year. But exchange rate kept on rising gradually from mid-2004 from Tk. 58/USD and reached to a peak of Tk. 70/USD in 2006, accounting a 20 percent depreciation. Since then, it remained fairly stable from 2007 to 2010 with slight fluctuation between 68 and 69. BDT again started depreciating against USD from early 2011 from tk. 69.40/USD and claimed to a maximum at 84.5 on 29 January 2012, reporting a 21.76 percent depreciation. Only in 2012, Bangladesh observed overall 10.0 percent depreciation against US dollar in FY12 due to higher import demand for enhanced domestic investment activities (caused huge foreign exchange demand for import of capital goods) and increase in fuel price. The weighted average interbank rate stood at Taka 81.83 per USD as on end June 2012 against 74.23 as on end June 2011. But, taka has regained its strength and appreciated due to prudent monetary policy. Strong growth of remittance from wage earners abroad (10.2 percent) and flow of foreign aid with rationalization of import payment and moderate growth of export (6.2 percent) helped to keep Bangladesh Taka competitive in this fiscal year. Therefore, the floating exchange rate regime in Bangladesh can be characterized as both volatile and stable.

As mentioned earlier, Bangladesh Bank intervenes in the foreign exchange market to prevent erratic undue movements in the exchange rates, to ensure adequate liquidity in the domestic foreign exchange market and to build official reserves. Therefore, the exchange rate regime of Bangladesh has not been in the purview of the freely floating rate regime, rather Bangladesh practices a managed floating rate system from the very beginning of its transition to floating regime. During 2012, Bangladesh Bank purchased USD 157.0 million (net) and sold USD 781.0 million in 2012 to make the foreign exchange market stable. Such intervention in the foreign exchange market is more precise from 2007 (Table-2) onwarddespite pressure from exporters and others to depreciate the currency. Exporters often demand depreciation to offset domestic price and wage inflation and regain competitiveness (Hossain and Ahmed, 2009).

Table 2: BB Intervention in the Foreign Exchange Market (USD million)

\begin{tabular}{|l|c|c|c|c|c|c|}
\hline Year & $\mathbf{2 0 0 7}$ & $\mathbf{2 0 0 8}$ & $\mathbf{2 0 0 9}$ & $\mathbf{2 0 1 0}$ & $\mathbf{2 0 1 1}$ & $\mathbf{2 0 1 2}$ \\
\hline Buy & 649.50 & 0 & 499.2 & 2161.00 & 316.5 & 157.0 \\
\hline Sell & 0 & 533.0 & 0 & 0 & 1279.0 & 781.0 \\
\hline Inter-bank transactions & 1919 & 3570 & 4511.78 & 6924.1 & 15020.3 & 29696.6 \\
\hline
\end{tabular}

Source: Bangladesh Bank Annual Report

\section{Literature Review}

This section surveys empirical contributions on various aspects about the effects of depreciation on price level and output level. Much research has been devoted to explaining the macroeconomic effects of exchange rate regimes, and researchers differ in methodologies and opinions, which makes the issue controversial.

Structuralists ${ }^{1}$ argue that the prices of tradable rise directly and the prices of non tradable may also rise depending on the labor markets conditions and on institutional arrangements such as wage indexation when there is depreciation. Even if the price of non-tradable goods does not raises in response to wage increases but remains sticky downward, devaluation may raise the general price level or its growth rate (Agenor 1991, Montiel 1997, Aghevli B.B. et al, 1991, Krugman and Taylor 1987).

Monetarist view is very different from that of the structuralists. They view inflation always and everywhere as a monetary phenomenon and argue that for sustained economic growth, macroeconomic stability is considered as a source of inflation as it affects income distribution significantly. An anticipated currency devaluation may increase the excess money supply and thereby inflation by lowering the demand for domestic currency (Hossain 2002).

${ }^{1}$ Structuralist is a school of economic thought of $20^{\text {th }}$ century led by economist RaúlPrebisch from Latin America and Celso Furtado from Brazi. Structuralist economics is an approach to economics that emphasizes the importance of taking into account structural features (typically) when undertaking economic analysis. Dutt and Ros (2003, p. 55) argue that structuralist economists try to identify specific rigidities, lags as well as other characteristics of the structure of developing countries in order to assess the way economies adjust and their responsiveness to development policies. 
A depreciation (or devaluation) of the domestic currency may stimulate economic activity through the initial increase in the price of foreign goods relative to home goods. By increasing the international competitiveness of domestic industries, exchange rate depreciation diverts spending from foreign goods to domestic goods argued by Magda Kandil (Kandil, 2004). Thus, depreciation may allow domestic output level to rise promoting spending for home products.

Marshall Lerner condition says that - 'Devaluation will improve the trade balance if the devaluing nation's demand elasticity for imports plus the foreign demand elasticity for the nation's exports exceed 1 (one).' If the Marshall-Lerner condition is not satisfied, currency depreciation could produce contraction. Hirseman (1949) points out this fact and conclude that currency depreciation from an initial trade deficit reduces real national income and may lead to a fall in aggregate demand.

Evidence from a recent study in Nigeria to examine the link among depreciation, inflation and output revealed a mixed result of exchange rate depreciation on output- contractionary in the short term and expansionary in the intermediate and long term. These results tend to suggest that depreciation does not necessarily lead to output expansion, particularly in the short-run (Odusola and Akinlo, 2001). Similar observations were found in a study conducted in Bangladesh context which entailed depreciation as a source of reduction in the cost of intermediation reducing interest rate and thereby easing credit constraint (Hossain\& Ahmed, 2009).

Therefore, possible outcomes of currency depreciation are- firstly, in the goods market, an unexpected depreciation of the domestic currency will make imports more expensive than export, which will increase the demand for domestic products, increasing domestic output and price. Secondly, in the money market, an unexpected depreciation of the domestic currency, relative to its anticipated future value, prompts agents to hold more domestic currency and increases the interest rate, effects investment spending adversely and so does the aggregate demand leaving price level to rise. Thirdly, on the supply side, changes in the exchange rate, both anticipated and unanticipated, make imported intermediate goods costly, producers are inclined to decrease imports of intermediate goods, decreasing domestic output and increasing the cost of production and, hence, the aggregate price level (Kandil,2004). Accordingly, the effects of exchange rate fluctuation are highly debatable from its theoretical background.

\section{Methodology}

Recent studies suggest that most macroeconomic time series are non-stationary in their levels, that is, they have unit roots. These series can be made stationary through differencing and/or detrading (Enders, 2009; Maddala, 1999). Using ADF (augmented Dickey-Fuller) test, the time series considered in this study have been tested for unit roots to check their stationarity. All variables are found to be stationary in level form except real GDP. That is, real GDP contains a unit root in level form. But at first difference level, real GDP becomes stationary. Consequently, all variables are used in level forms while real GDP is used at first difference level. Test for stationarity of different variables is shown in appendix-1. Finally, the ordinary least square (OLS) method is employed to arrive at the regression equation for the desired coefficients.

\subsection{Model for Inflation}

From the perspective of exchange rate change the discussion of inflation becomes relevant because of two major considerations. First, a change in the exchange rate is almost certain to cause a change in the domestic prices of tradable goods. Second, the prices of non-tradable goods are also likely to be affected because the non-tradable goods often use tradable inputs and the demand switch generated by initial change in the exchange rate may not elicit corresponding supply response from the non-tradable sector to leave prices unchanged (Hossain, 2002). As currency depreciation increases competitiveness, demand for exports may increase, while import demand may decrease, leading to increased aggregate demand. The monetary side of this is that the country's receipts from foreigners may exceed its outgoing payments, resulting in an improved balance of payments (Fan, 2002). The outcome of an increased supply of foreign currency is that our domestic currency will be short in supply. This will place upward pressure on the domestic currency; the monetary authorities will expand the money supply in order to neutralize the pressure in our managed floating exchange rate regime. Increases in the money supply raise price levels. This, together with the fact that imports become more expensive after depreciation, may result in higher price levels (Kandil and Mirzaie. 2008). Facing probable depreciation of domestic currency, price level is likely to rise over time and output level as well due to greater aggregate demand. The impact of depreciation of domestic currency can better be illustrated using the following flow chart: 
Figure 1: Impact of Depreciation of Domestic Currency

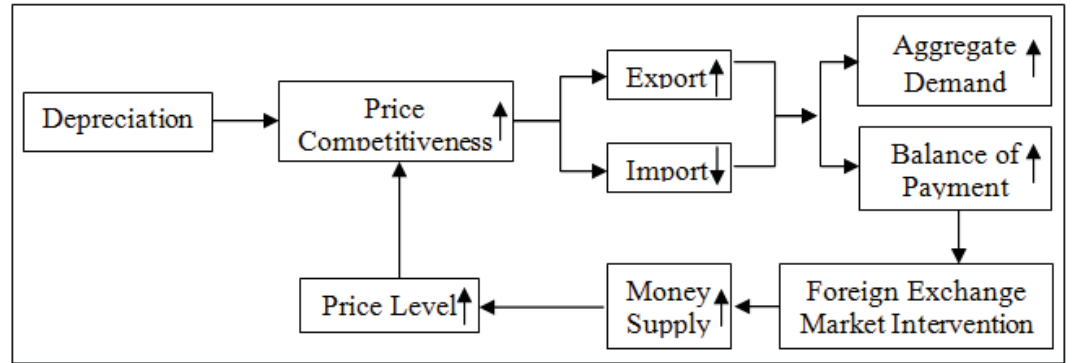

Therefore, theory and evidence suggest that, depreciation has a time varying effect on price and output level.

Assuming the price level changes in response to exchange rate fluctuation, the following models have been set. To examine how the effects of exchange rate fluctuations spread on inflation, we regress CPI (consumer price index) on exchange rate $(E)$. The regression analysis also includes a couple of control variables, variables that are also accountable for bringing about a substantial change in economy's price level. Such variables are real GDP (RGDP), narrow money $\left(\mathrm{M}_{1}\right)$, broad money $\left(\mathrm{M}_{2}\right)$, and bank credit $(\mathrm{BC})$. All these variables have a positive effect on inflation. The model also considers a lag value of $\mathrm{CPI}$ to incorporate the time varying effect of inflation. The study employs the data of real effective exchange rate (REER), as it is regarded as the best measure of the development of the real value of a country's currency against the basket of the trading partners of the country, is a frequently used variable in both theoretical and applied economic research and policy analysis.

Model-1:CPIt $=\beta_{0}+\beta_{1} E_{t}+\beta_{2} R G D P_{t}+\beta_{3} M_{1 t}+\beta_{4} B C_{t}+\beta_{5} C P I_{t-1}+U_{t}$

Model-2:CPIt $=\beta_{0}+\beta_{1} E_{t}+\beta_{2} R G D P_{t}+\beta_{3} M_{2 t}+\beta_{4} B C_{t}+\beta_{5} C P I_{t-1}+U_{t}$

\subsection{Model for Output Growth}

Following is the model used to study the effect of depreciation on output growth where capital stock (investment- I spending as a proxy), labor force $(\mathrm{L})$, lagged income have also been taken into account as explanatory variables to distinguish the relationship between exchange rate over growth. The model considers investment as it plays a vital role in capital stock change and thereby output growth. Labor force growth is another important factor that effects growth of an economy positively. And as shown earlier, lagged real GDP value is necessary to incorporate it's time diverging effect on growth which is expected to be positive as well.

$R G D P_{t}=\theta_{0}+\theta_{1} l_{t}+\theta_{2} E_{t}+\theta_{3} L_{t}+\theta_{4} R G D P_{t-1}+V_{t}$

Logarithmic transformation of the model would be useful to describe the degree of response of a change of price level and output level due to depreciation and fluctuations in other variables. Therefore, the models of inflation in logarithmic form are-

Model-1:InCPIt $=\beta_{0}+\beta_{1} \ln E_{t}+\beta_{2} \ln R G D P_{t}+\beta_{3} \ln _{1 t}+\beta_{4} \ln B C_{t}+\beta_{5} \ln C P I_{t-1}+U_{t}$

Model-2:InCPIt $=\beta_{0}+\beta_{1} \ln E_{t}+\beta_{2} \ln R G D P_{t}+\beta_{3} \ln M_{2 t}+\beta_{4} \ln B C_{t}+\beta_{5} \ln C P I_{t-1}+U_{t}$

For both the models, it is expected that $\beta_{1}, \beta_{2}, \beta_{3}$ and $\beta_{4}$ is positive while the sign of $\beta_{5}$ cannot be determined a priori. $U$ stands to show the residual term.

The model that better describes the effect of depreciation on output growth in logarithmic form is-

$\operatorname{lnRGDP}{ }_{\mathrm{t}}=\theta_{0}+\theta_{1} \ln _{\mathrm{t}}+\theta_{2} \ln \mathrm{E}_{\mathrm{t}}+\theta_{3} \ln _{\mathrm{t}}+\theta_{4} \operatorname{InRGDP}_{\mathrm{t}-1}+\mathrm{V}_{\mathrm{t}}$

Here all the coefficients $\left(\theta_{1}, \theta_{2}, \theta_{3}, \theta_{4}\right)$ are likely to be positive.

\subsection{Sample Period and Data Sources}

The study covers data of the period from 1981 to 2012. Annual secondary data of different variables collected from various sources have been employed to estimate the models. Data on GDP, investment, CPI and bank credit have been collected from the various issues of Statistical Year Book of Bangladesh, published by Bangladesh Bureau of Statistics (BBS). Labor force data of different years have been collected from 'Statistical Year Book of Bangladesh, Bangladesh Bureau of Statistics (BBS)' and CIA World Fact book. Data on real effective exchange rate, narrow money and broad 
money have been collected from various issues of Bangladesh Bank Annual Report. These data are found with different base years and then bases are converted into unit year, which is 1995-96(=100).

\section{Empirical Results}

The study reveals that fluctuations in exchange rate produces a considerable impact over both price level and output level. Both the models of inflation leave almost identical results in respect of the relationship between exchange rate and price level and the relationship is positive.

The empirical results of the regression models for inflation are as follows.

The estimated model for inflation (model-1)

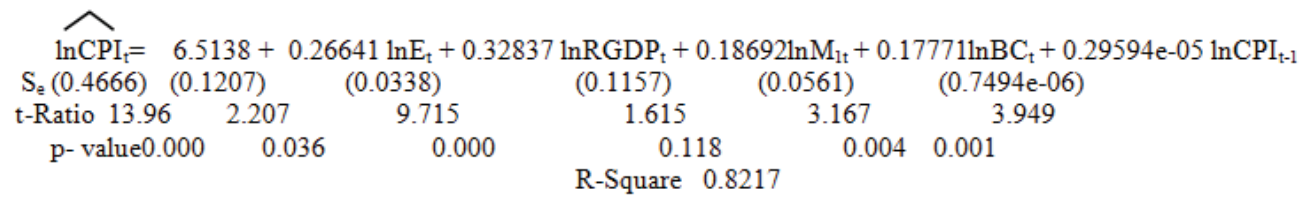

And, The estimated model for inflation (model-2)

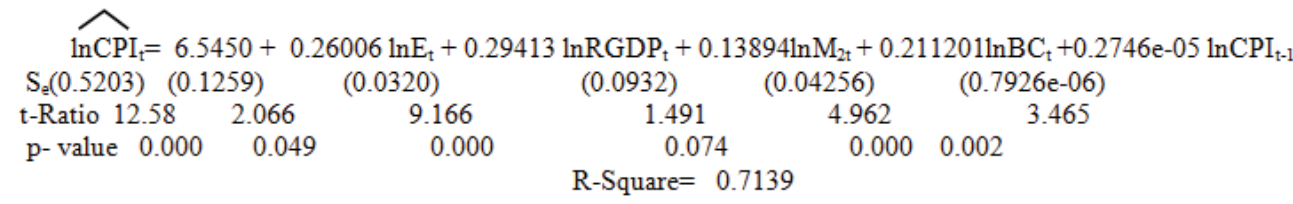

Table 3: Analysis of Variance Table (Model-01)

\begin{tabular}{|c|c|c|c|c|c|}
\hline & SS & DF & MS & $F$ & P-Value \\
\hline Regression & 1.1106 & 5 & 0.2221 & \multirow{3}{*}{28.758} & \multirow{3}{*}{0.000} \\
\hline Error & 0.20082 & 26 & 0.0077 & & \\
\hline Total & 1.3114 & 31 & 0.0423 & & \\
\hline
\end{tabular}

Table 4: Analysis of Variance Table (Model-02)

\begin{tabular}{|l|c|c|c|c|c|}
\hline & SS & DF & MS & F & P-Value \\
\hline Regression & 1.0978 & 5 & 0.2196 & \multirow{2}{*}{26.715} & \multirow{2}{*}{0.000} \\
\hline Error & 0.21368 & 26 & 0.0082 & \\
\hline Total & 1.3114 & 31 & 0.0423 & & \\
\hline
\end{tabular}

Both the models exhibit all most identical result for the cause of inflation. Price inflation which is displayed through the growth in $\mathrm{CPI}$ reacts positively towards exchange rate change, meaning that rise in exchange rate leads to price inflation. It means that depreciation or devaluation leads an economy to price inflation and test result shows that one per cent depreciation in exchange rate causes price level to rise by 0.2664 per cent for model 1 and for model 2 it varies slightly to 0.26 per cent, but both are statistically significant at 5 percent level.

The study also reveals that all other factors (RGDP, $B C, M_{1}, M_{2}$ ) influence price level to change positively with little variation between the models except the legged value of $\mathrm{CPI}$ which signifies the absence of time varying effect of inflation and thus the estimated models for inflation maintain the expected signs of the coefficients as they are likely to be hold. Growth of real GDP causes inflation and if real income rises by 1 per cent, price level rises by 0.3283 per cent and 0.2941 percent for model-1 and model-2 respectively. Similarly, if the bank credit rises by 1 per cent, inflation rises by 0.1777 per cent and 0.2112 per cent for the models correspondingly. Moreover, a 1 per cent increase in the supply of narrow money $\left(\mathrm{M}_{1}\right)$ leads to 0.1869 per cent inflation, while it varies to 0.1389 per cent for the case of broad money $\left(\mathrm{M}_{2}\right)$. 
However, all the coefficients are statistically significant at 5 percent level except $M_{1}$ and $M_{2}$, but the overall significance test shows that all the slope parameters are statistically different from zero, which is statistically significant.

The model estimated for output growth yields the following result.

\begin{tabular}{|c|c|c|c|c|c|}
\hline $\mathrm{S}_{\mathrm{e}}$ & $\begin{array}{l}\ln R G \mathrm{~L} \\
(4.8901)\end{array}$ & $\begin{array}{l}\mathrm{P}_{\mathrm{t}}=7.10 \\
(2.8762)\end{array}$ & $(0.1747)$ & $\begin{array}{l}\mathrm{1}_{\mathrm{t}}+0.8419 \mathrm{ln} \\
(0.2646)\end{array}$ & $\begin{array}{l}\mathrm{E}_{\mathrm{t}}+0.5312 \mathrm{li} \\
(1.2661)\end{array}$ \\
\hline t-Ratio & 1.452 & 1.058 & 4.82 & 2.083 & 1.604 \\
\hline $\mathrm{p}$-value & 0.000 & 0.03 & 0.000 & 0.047 & 0.121 \\
\hline & & & R-S & quare $=0.78$ & \\
\hline
\end{tabular}

Table 5: Analysis of Variance Table

\begin{tabular}{|l|c|c|c|c|c|}
\hline & SS & DF & MS & F & P-Value \\
\hline Regression & 52.812 & 5 & 10.562 & \multirow{3}{*}{399.747} & \multirow{2}{*}{0.000} \\
\cline { 1 - 4 } Error & 0.68698 & 26 & 0.0264 & \\
\cline { 1 - 4 } Total & 53.498 & 31 & 1.7258 & & \\
\hline
\end{tabular}

While investment spending, exchange rate and labor force contain expected positive significant coefficient (at 5\% level), government expenditure is insignificant. The overall significance test shows that all the slope parameters are statistically different from zero, and test result is statistically significant.

Since the coefficient associated with exchange rate is positive and significant, it implies that the effect of currency depreciation is expansionary in Bangladesh, a 1 per cent currency depreciation would boost our economy by 0.84 per cent. Such finding justifies exporters demand for depreciation to offset domestic price and wage inflation to regain competitiveness.

Likewise, 1 percent increase in investment spending boosts up the domestic output level by 3.04 percent and economy experiences a growth of 2.03 percent due to 1 percent rise in government expenditure though the result is termed to insignificant. Most importantly, labor force growth contributes the least to our economic growth, only .55 percent due to 1 percent increase in labor force.

Therefore, it is evident from the study that depreciation has a unidirectional impact over both price level and output growth. A related but equally important finding of this study is real national income growth also led to inflation. Thus, the overall results are consistent with the view that, in Bangladesh, depreciation usually leads to inflation fostering the output growth.

\section{Policy Recommendations and Conclusion}

Findings of the study have some policy implications for developing countries like Bangladesh. Depreciation, causes mainly due to external sector fluctuation, has an expansionary effect on output growth and price level. Government and monetary authorities change policies relating to foreign exchange regulation in response to changing external condition, which is essential to regain competitiveness of our exportable products by offsetting our domestic price and wage inflation. Globalization has made international business open and easier and at the same times the participating countries are facing gradual mutual competition in the international market, Bangladesh is no exception in this regard. It necessitates the need for proper exchange rate management to uphold the export competitiveness and at the same time to ensure the commodity supply at competitive price in the world market. Again, our export is largely dependent on our import. Most of the raw materials of the exportable goods industries are being imported from abroad. Recently, Due to the dictation of IMF to pursue contractionary monetary policies, the import of intermediate goods, industrial raw materials and capital machineries have been declined considerably. Besides, with the rise in petroleum-product imports to feed the liquid fuel-based power plants along with purchasing electricity from the fuel oil-fired rental power plants, increased cost stemming from supply has pushed inflationary pressures, and with the depreciation of taka it suggests an adverse implication on Bangladesh economy in meeting export targets and thereby attaining long term growth target. 


\section{References}

Agenor, P.R. (1991). "Output, Devaluation and the Real Exchange Rate in Developing Countries," Review of World Economics, WeltwirtschaftlichesArchive, Bd. 127, H. 1 (1991), pp. 18-41

Aghevli, B.B., Mohsin, S.K. and Montiel, P.J. (1991)."Exchange Rate Policy in Developing Countries: Some Analytical Issues", Occasional Paper no. 78, IMF.

Bangladesh Economic Review, Various Issues, Economic Adviser's Wing, Finance Division, Ministry of Finance, GOB, Dhaka.

Bangladesh Bank Annual Report, Various Issues.Reseaech Division, Bangladesh Bank.

Bangladesh Economic Update, (2013).UnnayanOnneshan, Economic Policy Unit, Volume 4, No. 2.

Dutt, A. K. and Ros, J.(2003)."Development Economics and Structuralist Macroeconomics: Essays in honor of Lance Taylor", Edward Elgar Publishing Ltd.

Enders W.(2009).Applied Econometric Times Series, 3rd Edition, John Wiley \& Sons, Inc.

Fan, E. X.(2002). Implications of a US Dollar Depreciation for Asian Developing Countries, ERD Policy Brief Series No. 11, Economics and Research Department, Asian Development Bank.

Hirschman, A.O. (1949). "Devaluation and the Trade Balance: A Note," Review of Economics and Statistics, Vol. 31, No. 1, 50-53.

Hossain,A. (2002). "Exchange Rate Responses to Inflation in Bangladesh",International Monetary Fund (IMF), October 2002, IMF Working Paper No. 02/166

HossainM.,\&Ahmed M. (2009). "An Assessment of Exchange Rate Policy under Floating Regime in Bangladesh", The Bangladesh Development Studies, Vol. XXXII, December 2009, No. 4.

Kandil M.(2004). "Exchange Rate Fluctuations and Economic Activity in Developing Countries: Theory and Evidence", Journal Of Economic Development, Volume 29, Number 1.

Kandil, M. and Mirzaie I. A. (2008). "Comparative Analysis of Exchange Rate Appreciation and Aggregate Economic Activity: Theory and Evidence from Middle Eastern Countries", Bulletin of Economic Research, Vol. 60, Issue 1, pp. 45-96.

Khondker, B. H., Bidisha, S. H. \&Razzaque, M. A. (2012)."The Exchange Rate and Economic Growth: An Empirical Assessment on Bangladesh", Working Paper, Country project on Bangladesh, International Growth Centre (IGC), UK.

Kollmann, R. (2005).'Macroeconomic Effects of Nominal Exchange Rate Regimes: New Insights into the Role of Price Dynamics', Journal of International Money and Finance, Vol. 24, pp. 275-292.

Krugman P. and Taylor, L. (1987). "Contractionary Effects of Devaluation," Journal of International Economics, Vol. 8, Issue 3, ,pp 445456

MaddalaG. S. (1999). A Comparative Study of Unit Root Tests with Panel Data and a New Simple Test, Oxford Bulletin Of Economics And Statistics, Special Issue.

Montiel, P.J. (1997). ÒExchange Rate Policy and Macroeconomic Management inASEAN Countries.ÓMacroeconomic Issues Facing ASEAN Countries. Washington, D.C.: IMF

Odusola, A. F. and Akinlo, A. E. (2001). "Output, Inflation and Exchange Rate in Developing Countries: An Application to Nigeria", The Developing Economies, XXXIX-2, 199-222

\section{Appendix}

Appendix-1: ADF Stationarity Test: Null hypothesis- The variables are non-stationary

\begin{tabular}{|c|c|c|c|}
\hline Variable & Difference & ADF Test-Statistic & Decision \\
\hline $\operatorname{InCPI}$ & Level & -4.913 & Stationary \\
\hline $\operatorname{InRGDP}$ & Level & -1.413 & Non-stationary \\
\hline $\operatorname{InRGDP}$ & First Difference & -3.575 & Stationary \\
\hline $\operatorname{lnE}$ & Level & -4.131 & Stationary \\
\hline $\ln l$ & Level & -5.337 & Stationary \\
\hline $\ln \mathrm{M}_{1}$ & Level & -3.970 & Stationary \\
\hline $\operatorname{lnM} \mathrm{M}_{2}$ & Level & -3.65 & Stationary \\
\hline $\operatorname{lnBC}$ & Level & -3.727 & Stationary \\
\hline $\ln L$ & Level & -6.081 & \\
\hline
\end{tabular}

Critical values for ADF statistics at $5 \%$ and $10 \%$ level of significance are -3.50 and -3.18 , respectively. The null hypothesis- the series is non-stationary, or contains a unit root has been rejected for all variables except real GDP. Real GDP is stationary at first difference level. 